\title{
Chloroplast SSR genetic diversity indicates a refuge for Corylus avellana in northern Portugal
}

\author{
S. Martins $\cdot$ F. Simões $\cdot$ D. Mendonça $\cdot$ \\ J. Matos · A. P. Silva $\cdot$ V. Carnide
}

Received: 26 April 2012/Accepted: 1 October 2012/Published online: 12 October 2012

(C) Springer Science+Business Media Dordrecht 2012

\begin{abstract}
The genus Corylus, a member of the birch family Betulaceae, includes several species that are widely distributed throughout temperate regions of the Northern Hemisphere. The development of microsatellites or simple sequence repeats (SSRs) for noncoding regions of the chloroplast genome and their higher sequence variation compared with coding regions has provided a higher resolution tool for the study of cultivars and closely related taxa. Chloroplast polymorphisms provide a marker system to evaluate the genetic structure of plant populations. This study investigated genetic diversity in three cultivars and 32
\end{abstract}

S. Martins $(\varangle) \cdot$ V. Carnide

Department of Genetics and Biotechnology,

University of Trás-os-Montes and Alto Douro,

5001-801 Vila Real, Portugal

e-mail: sandram@utad.pt

F. Simões $\cdot$ D. Mendonça $\cdot$ J. Matos

Molecular Biology Group (GBM)/Genetic Resources, Ecophysiology and Plant Breeding Unit, INRB, Estrada do Paço do Lumiar, 22, 1649-038 Lisbon, Portugal

\section{A. P. Silva}

Centre for the Research and Technology of AgroEnvironment and Biological Sciences, University of Trás-os-Montes and Alto Douro, 5001-801 Vila Real, Portugal

\section{Carnide}

Institute for Biotechnology and Bioengineering Centre of Genomics and Biotechnology, University of Trás-osMontes and Alto Douro, 5001-801 Vila Real, Portugal genotypes of Corylus avellana L. from Portugal: 13 wild genotypes and 19 Portuguese landraces. Four of ten cpSSR loci were polymorphic, with diversity indices ranging from 0.111 to 0.244 . Eleven chlorotypes were detected, and their relationships were analyzed using a network model. Haplotype A was most frequent in landraces and cultivars. Four chlorotypes ( H, I, J and L) were found only in wild hazelnuts. The diversity of chlorotypes in the wild hazels, and the limited number reported in cultivars, suggests that northern Portugal was a refuge for hazel during the last ice age.

Keywords Chlorotype - Corylus avellana Filbert . Hazelnut $\cdot$ Microsatellite

\section{Introduction}

Two different Corylus species are present in Europe: the European hazel, C. avellana L., which has a wide distribution, and the Turkish tree hazel, C. colurna L., restricted to the Balkans, Romania, and northern Turkey with isolated trees also reported in Iran and Georgia (Thompson et al. 1996). European hazel (C. avellana) is a member of the Betulaceae. The geographic distribution of European hazel extends from the Mediterranean coast of North Africa northward to the British Islands and the Scandinavian, and eastward to the Ural Mountains of Russia, the Caucasus Mountains, Iran, and Lebanon (Kasapligil 
1972). Important cultivars in Europe and Turkey were selected over many centuries from local wild populations (Trotter 1921; Tasias Valls 1975; Thompson et al. 1996). Turkey has long been the world's leading producer and exporter of hazelnuts, accounting for about $71 \%$ of world production (FAOstat 2008). Among trees nuts, European hazel is the fifth commercially most important after cashew (Anacardium occidentale L.), almond [Prunus dulcis (Miller) D. A. Webb], walnut (Juglans regia L.), coconut (Cocos nucifera L.) and chestnut (Castanea spp.). The use of hazelnuts dates to prehistoric times (Gokirmak et al. 2009). Hazelnuts are consumed as natural, blanched and roasted kernels, or as processed products including sliced, chopped kernels, hazelnut flour, oil and butter. In Portugal, hazelnut production has suffered a sharp decline since the 1990s, which saw the abandonment of its cultivation in favor of agronomic crops leading to the loss of local landrace. The number of landrace genotypes identified in Portugal is low and are denominated Molar, Grada de Viseu, Veiga and Comum (Silva et al. 2004). The loss of landrace genotypes can reduce the genetic diversity of residual populations, which is potentially catastrophic since genetic diversity is widely recognized as a key requirement for the long-term survival of species on an evolutionary time-scale. Genetic diversity provides the template for adaptation, evolution and survival of populations and species, especially in environments that are subject to climate change or to introduction of new pests, pathogens or competitors (Rajora and Mosseler 2001). Genetic analysis of populations requires suitable multivariate markers that can elucidate fine-scale details of spatial structure (Streiff et al. 1998) and reconstruct gene flow patterns (Streiff et al. 1999). Microsatellites or SSRs are highly polymorphic co-dominant markers generated by the polymerase chain reaction (PCR). Recently, nuclear SSRs were investigated in hazelnut and used for genotyping and phylogeny studies (Bassil et al. 2005; Boccacci et al. 2005, 2006; Gokirmak et al. 2009; Gürcan and Mehlenbacher 2010; Gürcan et al. 2010). Microsatellites also occur in the chloroplast genome of higher plants (Powell et al. 1995, 1996). These cpDNA microsatellites are usually single nucleotide repeats, mainly A-T repeats, and are highly polymorphic (Provan et al. 1999, 2001). In plants, cpSSRs have been widely employed in population and evolution studies and have proven to be particularly useful for deducing re-colonization routes and identification of hybridization events (Navascues and Emerson 2005; Boccacci and Botta 2009). Comparative analyses of nuclear and chloroplast microsatellites have become popular approaches because they can provide complementary and often contrasting information on genetic structure, differentiation and gene flow (pollen- and seed-mediated) within and among populations (Birky 1988; McCauley 1995; Ennos et al. 1999; Weising and Gardner 1999; Ishii et al. 2001; Lira et al. 2003; Ueno et al. 2005). Genetic diversity and differentiation measures derived from these markers can also support policies regarding conservation priorities for populations of threatened species (Petit et al. 1998). In angiosperms, chloroplast genomes are predominantly maternally inherited (mainly transmitted through the female gamete) and, thus, can reveal maternal lineages (Radetzky 1990; Rajora and Dancik, 1992; Birky 1995; Dumolin et al. 1995). This make them particularly sensitive to the effects of population fragmentation; partly because they have smaller effective population sizes than nuclear genomes and partly because seed-mediated gene dispersal is generally more limited than pollen-mediated gene flow (Pakkad et al. 2008). Consequently, chloroplast-specific markers are likely to provide good indicators of historical bottlenecks, founder effects and genetic drift (Li et al. 2007). In case of $C$. avellana chloroplast genomes inheritance is maternal. Since the number of landrace genotypes actually identified in Portugal was low, the aim of this work was to ascertain the level of maternal genetic diversity and differentiation of wild and landrace genotypes of $C$. avellana, by using cpSSR markers.

\section{Materials and methods}

A total of 35 hazelnut accessions were used in this study: three cultivars, 19 landraces and 13 wild plants. 'Butler', 'Merveille de Bollwiller' and 'Longue d'Espagne' were included as controls. The 19 landrace genotypes were collected within an area of approximately $27,000 \mathrm{~km}^{2}$, located between Northern and Central Portugal (latitude 40.30-41.70 and longitude 6.29-8.35) (Fig. 1). This area was recognized an area of hazelnut production in olden times (until 1980) (Galvão, 1968). The identification and location of these landrace genotypes was carried out by collecting 
Fig. 1 Map of northern Portugal showing sampling sites

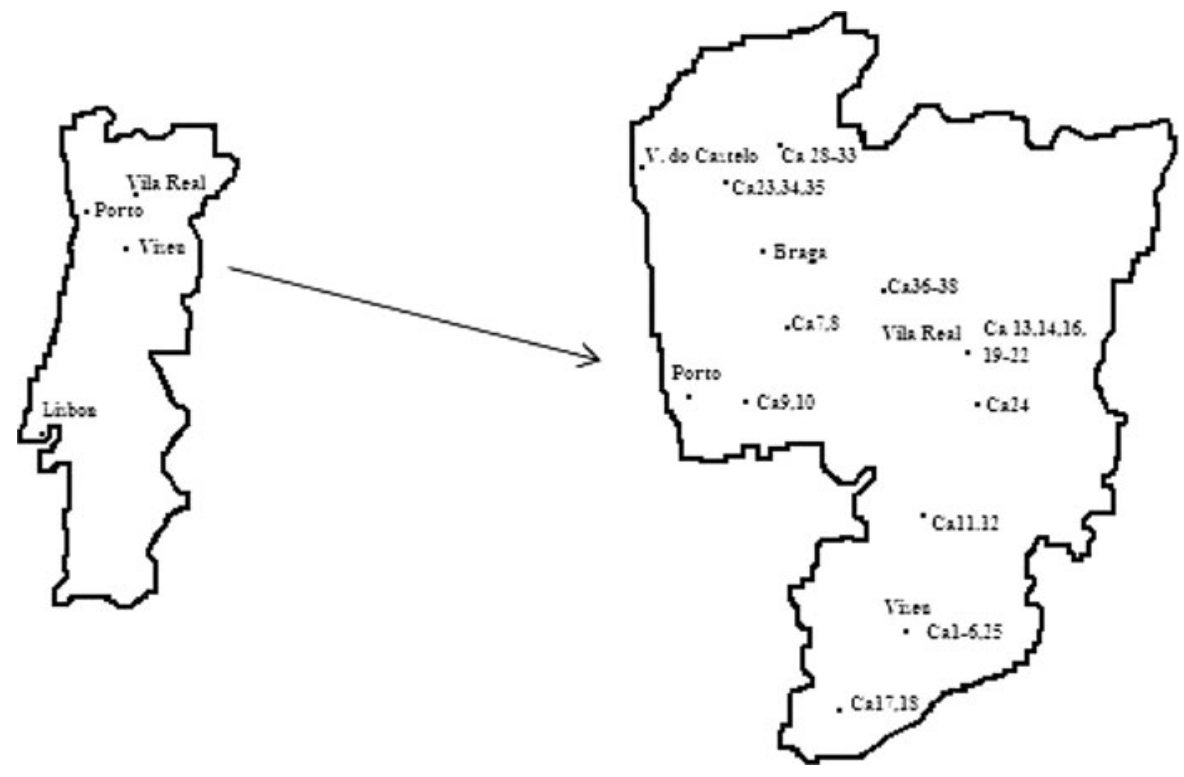

oral testimonials from farmers and other older people in the region. Testimony confirmed that the landraces had existed in the region for $>75$ years (predating the World War II). Some of these accessions were previously included in the European Project Safenut (AGRI GEN RES 068). From each site we collected landrace genotypes showing morphological differences and appearing to be $>75$ years old. To avoid sampling related genotypes or resampling clones, all individuals selected were separated by at least $200 \mathrm{~m}$. We searched for wild genotypes in natural and national parks with the collaboration of forest keepers who had knowledge of the existence and the location of the wild hazelnuts. Sampling in such parks was preferred due to their conservation value of the areas and because they are wild genotypes. Table 1 lists the accessions used in this study by group, and gives the geographical coordinates of each collection site. Immature catkins were collected in the field and kept cool during the transportation (about $2 \mathrm{~h}$ ) and frozen in a $-80{ }^{\circ} \mathrm{C}$ freezer. Total genomic DNA was extracted by using the a DNeasy kit (Qiagen) (Hilden, Germany), following the manufacturer's instructions. DNA concentration was determined by both spectrophotometry at $260 \mathrm{~nm}$ and gel electrophoretic analysis. The ten cpSSR loci in analysis comprised ccmp1, ccmp2, ccmp3, ccmp4, ccmp5, ccmp6, ccmp7 and ccmp10 (Weising and Gardner 1999), and cmcs1 and cmcs4 (Sebastiani et al. 2004) designed for Nicotiana tabacum L. and Castanea sativa Mill., respectively.
PCR amplification was carried out with a reaction mixture $(20 \mu \mathrm{l})$ consisting of $50 \mathrm{ng}$ of template DNA, $10 \mu \mathrm{M}$ of each primer, $200 \mu \mathrm{M}$ dNTPs, $2 \mathrm{mM} \mathrm{MgCl}_{2}$, $2 \mu \mathrm{l} 10 \times\left(\mathrm{NH}_{4}\right)_{2} \mathrm{SO}_{4}$ buffer and 1 unit of Taq DNA polymerase (Fermentas) (Germany). All cpSSR amplifications were performed under the following temperature cycling conditions: 3 min of denaturation at $94{ }^{\circ} \mathrm{C}$, followed by 35 cycles of $30 \mathrm{~s}$ at $94{ }^{\circ} \mathrm{C}, 30 \mathrm{~s}$ at $50{ }^{\circ} \mathrm{C}$, and $30 \mathrm{~s}$ at $72{ }^{\circ} \mathrm{C}$; and a final 20-min extension step at $72{ }^{\circ} \mathrm{C}$. PCR products were separated on an ABI Prism 310 Genetic Analyzer (Applied Biosystems, FosterCity, CA, USA). Results were processed with GeneMapper software and allele sizes (in base pairs, bp) were estimated from the GeneScan350 ROX size standard (Applied Biosystems). The cpSSR data were analyzed with Popgene 1.32 software (Yeh et al. 1999). A chlorotype median network was constructed in the program Network v. 4.5 (Bandelt et al. 1999).

\section{Results}

Of the ten pairs of chloroplast microsatellite primers, only four were polymorphic (Table 2). Locus ccmp2 showed four size variants, while ccmp4 showed three and ccmp 3 and ccmp10 each showed two. Considering the allelic variants at the four loci, eleven different haplotypes were detected among the 35 genotypes and their relationships were analyzed under a median 
Table 1 Chlorotypes and origins of C. avellana genotypes studied

\begin{tabular}{|c|c|c|c|c|c|c|}
\hline Accession & Group & Haplotype & Region & Local & Longitude & Latitude \\
\hline 1 & Landrace & A & Center & Viseu & $7^{\circ} 56^{\prime} \mathrm{W}$ & $40^{\circ} 39^{\prime} \mathrm{N}$ \\
\hline 2 & Landrace & $\mathrm{B}$ & Center & Viseu & $7^{\circ} 56^{\prime} \mathrm{W}$ & $40^{\circ} 39^{\prime} \mathrm{N}$ \\
\hline 3 & Landrace & A & Center & Viseu & $7^{\circ} 56^{\prime} \mathrm{W}$ & $40^{\circ} 39^{\prime} \mathrm{N}$ \\
\hline 4 & Landrace & $\mathrm{B}$ & Center & Viseu & $7^{\circ} 48^{\prime} \mathrm{W}$ & $40^{\circ} 39^{\prime} \mathrm{N}$ \\
\hline 5 & Landrace & $\mathrm{D}$ & Center & Viseu & $7^{\circ} 54^{\prime} \mathrm{W}$ & $40^{\circ} 39^{\prime} \mathrm{N}$ \\
\hline 6 & Landrace & A & Center & Viseu & $7^{\circ} 49^{\prime} \mathrm{W}$ & $40^{\circ} 38^{\prime} \mathrm{N}$ \\
\hline 7 & Landrace & B & Littoral & Felgueiras & $8^{\circ} 10^{\prime} \mathrm{W}$ & $41^{\circ} 22^{\prime} \mathrm{N}$ \\
\hline 8 & Landrace & $\mathrm{B}$ & Littoral & Felgueiras & $8^{\circ} 10^{\prime} \mathrm{W}$ & $41^{\circ} 22^{\prime} \mathrm{N}$ \\
\hline 9 & Landrace & $\mathrm{C}$ & Littoral & Castelo de Paiva & $8^{\circ} 16^{\prime} \mathrm{W}$ & $41^{\circ} 02^{\prime} \mathrm{N}$ \\
\hline 10 & Landrace & A & Littoral & Castelo de Paiva & $8^{\circ} 16^{\prime} \mathrm{W}$ & $41^{\circ} 02^{\prime} \mathrm{N}$ \\
\hline 11 & Landrace & $\mathrm{E}$ & Center & Moimenta da Beira & $7^{\circ} 34^{\prime} \mathrm{W}$ & $40^{\circ} 57^{\prime} \mathrm{N}$ \\
\hline 12 & Landrace & A & Center & Moimenta da Beira & $7^{\circ} 34^{\prime} \mathrm{W}$ & $40^{\circ} 57^{\prime} \mathrm{N}$ \\
\hline 13 & Cultivar & B & UTAD & Vila Real & $7^{\circ} 44^{\prime} \mathrm{W}$ & $41^{\circ} 17^{\prime} \mathrm{N}$ \\
\hline 14 & Cultivar & B & UTAD & Vila Real & $7^{\circ} 44^{\prime} \mathrm{W}$ & $41^{\circ} 17^{\prime} \mathrm{N}$ \\
\hline 16 & Cultivar & A & UTAD & Vila Real & $7^{\circ} 44^{\prime} \mathrm{W}$ & $41^{\circ} 17^{\prime} \mathrm{N}$ \\
\hline 17 & Landrace & A & Center & Tondela & $8^{\circ} 04^{\prime} \mathrm{W}$ & $40^{\circ} 30^{\prime} \mathrm{N}$ \\
\hline 18 & Landrace & B & Center & Tondela & $8^{\circ} 04^{\prime} \mathrm{W}$ & $40^{\circ} 30^{\prime} \mathrm{N}$ \\
\hline 19 & Landrace & $\mathrm{F}$ & Inland & Vila Real & $7^{\circ} 45^{\prime} \mathrm{W}$ & $41^{\circ} 19^{\prime} \mathrm{N}$ \\
\hline 20 & Landrace & A & Inland & Vila Real & $7^{\circ} 44^{\prime} \mathrm{W}$ & $41^{\circ} 19^{\prime} \mathrm{N}$ \\
\hline 21 & Landrace & A & Inland & Vila Real & $7^{\circ} 44^{\prime} \mathrm{W}$ & $41^{\circ} 19^{\prime} \mathrm{N}$ \\
\hline 22 & Landrace & G & Inland & Vila Real & $7^{\circ} 44^{\prime} \mathrm{W}$ & $41^{\circ} 19^{\prime} \mathrm{N}$ \\
\hline 23 & Wild & $\mathrm{H}$ & Littoral & Ponte de Lima & $8^{\circ} 35^{\prime} \mathrm{W}$ & $41^{\circ} 44^{\prime} \mathrm{N}$ \\
\hline 24 & Wild & A & Littoral & PNDI & $6^{\circ} 29^{\prime} \mathrm{W}$ & $40^{\circ} 30^{\prime} \mathrm{N}$ \\
\hline 25 & Landrace & A & Center & Viseu & $7^{\circ} 48^{\prime} \mathrm{W}$ & $40^{\circ} 39^{\prime} \mathrm{N}$ \\
\hline 28 & Wild & I & Littoral & PNPG & $8^{\circ} 15^{\prime} \mathrm{W}$ & $41^{\circ} 56^{\prime} \mathrm{N}$ \\
\hline 29 & Wild & I & Littoral & PNPG & $8^{\circ} 15^{\prime} \mathrm{W}$ & $41^{\circ} 56^{\prime} \mathrm{N}$ \\
\hline 30 & Wild & $\mathrm{J}$ & Littoral & PNPG & $8^{\circ} 15^{\prime} \mathrm{W}$ & $41^{\circ} 56^{\prime} \mathrm{N}$ \\
\hline 31 & Wild & I & Littoral & PNPG & $8^{\circ} 22^{\prime} \mathrm{W}$ & $41^{\circ} 70^{\prime} \mathrm{N}$ \\
\hline 32 & Wild & $\mathrm{L}$ & Littoral & PNPG & $8^{\circ} 22^{\prime} \mathrm{W}$ & $41^{\circ} 70^{\prime} \mathrm{N}$ \\
\hline 33 & Wild & I & Littoral & PNPG & $8^{\circ} 22^{\prime} \mathrm{W}$ & $41^{\circ} 70^{\prime} \mathrm{N}$ \\
\hline 34 & Wild & I & Littoral & Ponte de Lima & $8^{\circ} 35^{\prime} \mathrm{W}$ & $41^{\circ} 44^{\prime} \mathrm{N}$ \\
\hline 35 & Wild & I & Littoral & Ponte de Lima & $8^{\circ} 35^{\prime} \mathrm{W}$ & $41^{\circ} 44^{\prime} \mathrm{N}$ \\
\hline 36 & Wild & I & Inland & PNA & $7^{\circ} 49^{\prime} \mathrm{W}$ & $41^{\circ} 22^{\prime} \mathrm{N}$ \\
\hline 37 & Wild & $\mathrm{H}$ & Inland & PNA & $7^{\circ} 49^{\prime} \mathrm{W}$ & $41^{\circ} 22^{\prime} \mathrm{N}$ \\
\hline 38 & Wild & $\mathrm{L}$ & Inland & PNA & $7^{\circ} 49^{\prime} \mathrm{W}$ & $41^{\circ} 22^{\prime} \mathrm{N}$ \\
\hline
\end{tabular}

network model (Fig. 2). The distribution of these haplotypes among the three different levels of human selection was not uniform (Table 3). Haplotype A was observed in nine landraces, one wild genotype, and in 'Merveille de Bollwiller'. Haplotype B was common in the landraces but was absent in the wild genotypes. Five rare haplotypes $(\mathrm{C}, \mathrm{D}, \mathrm{E}, \mathrm{F}$ and $\mathrm{G})$ were found in the landraces, but were absent in the wild genotypes and cultivars. One wild genotype from Peneda-Gerês
National Park showed the rarest haplotype (J). The two main haplotypes (A and $\mathrm{B}$ ) were present in the cultivars and landraces, and haplotype $\mathrm{A}$ was also present in one wild genotype. Haplotypes H, I, J and L were found only in wild genotypes north of the Douro River and were absent in the cultivars and landraces. Haplotype I was the most frequent in the wild genotypes. Chlorotype $\mathrm{H}$ was detected in two wild accessions, one from Ponte de Lima and one from 
Table 2 Eleven chlorotypes based on four polymorphic cpSSR loci. Allele sizes are in base pairs as determined by capillary electrophoresis

\begin{tabular}{lllll}
\hline Haplotype & Ccmp2 & Ccmp3 & Ccmp4 & Ccmp10 \\
\hline A & 213 & 117 & 115 & 106 \\
B & 213 & 117 & 116 & 106 \\
C & 213 & 116 & 116 & 106 \\
D & 213 & 117 & 114 & 106 \\
E & 213 & 117 & 115 & 105 \\
F & 214 & 117 & 115 & 105 \\
G & 214 & 117 & 115 & 106 \\
H & 217 & 117 & 115 & 106 \\
I & 217 & 117 & 114 & 106 \\
J & 218 & 117 & 114 & 106 \\
L & 217 & 117 & 114 & 105 \\
\hline
\end{tabular}

Six of ten cpSSR loci were monomorphic: Ccmp1 (129 bp), Ccmp5 (107 bp), Ccmp6 (97 bp), Ccmp7 (153 bp), Cmcs1 (102 bp) and Cmcs4 (107 bp)

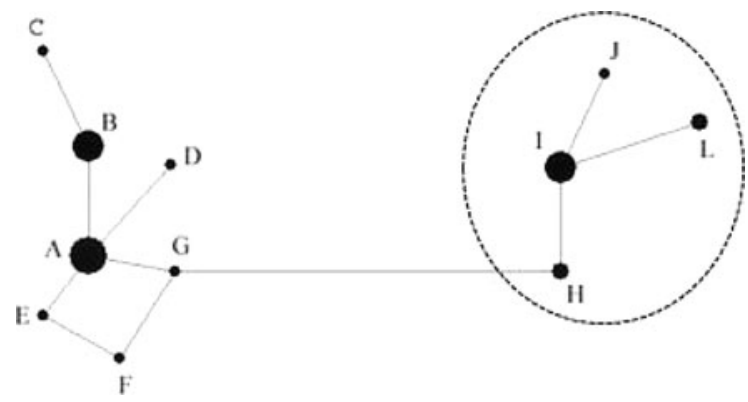

Fig. 2 Median network of 11 haplotypes identified in 35 hazelnut genotypes. Circle areas are proportional to haplotype frequencies. The haplotypes within the dashed circle were only found in wild genotypes

Alvão Natural Park while haplotype L was found in two wild accessions, one from Peneda-Gerês National Park and another from Alvão Natural Park. Genetic diversity $(\mathrm{H})$ values observed in the group of wild genotypes and landrace genotypes were 0.244 and 0.222 , respectively. Diversity at the four polymorphic cpSSR loci was 0.359 . Diversity within groups was $0.192, \mathrm{G}_{\mathrm{ST}}$ was 0.425 and $\mathrm{Nm}$ was 0.676 .

\section{Discussion}

The ten cpSSR primer pairs were those used by Boccacci and Botta (2009) and included the six used by
Table 3 Chlorotype number and frequency in 32 Portuguese C. avellana genotypes and three cultivars

\begin{tabular}{|c|c|c|c|c|}
\hline & \multirow{2}{*}{$\begin{array}{l}\text { Wild } \\
\text { genotypes }\end{array}$} & \multicolumn{3}{|c|}{ Cultivated forms } \\
\hline & & $\begin{array}{l}\text { Landrace } \\
\text { genotypes }\end{array}$ & Cultivars & Total \\
\hline Haplotype A & $1(0.077)$ & $9(0.474)$ & $1(0.333)$ & $11(0.314)$ \\
\hline Haplotype B & & $5(0.263)$ & $2(0.667)$ & $7(0.200)$ \\
\hline Haplotype C & & $1(0.053)$ & & $1(0.028)$ \\
\hline Haplotype D & & $1(0.053)$ & & $1(0.028)$ \\
\hline Haplotype E & & $1(0.053)$ & & $1(0.028)$ \\
\hline Haplotype F & & $1(0.053)$ & & $1(0.028)$ \\
\hline Haplotype G & & $1(0.053)$ & & $1(0.028)$ \\
\hline Haplotype H & $2(0.154)$ & & & $2(0.057)$ \\
\hline Haplotype I & $7(0.538)$ & & & $7(2.000)$ \\
\hline Haplotype J & $1(0.077)$ & & & $1(0.028)$ \\
\hline Haplotype L & $2(0.154)$ & & & $2(0.057)$ \\
\hline $\mathrm{N}$ & 5 & 7 & 2 & 11 \\
\hline $\mathrm{H}$ & 0.222 & 0.244 & 0.111 & 0.359 \\
\hline
\end{tabular}

$n$ number of samples, $N$ number of haplotypes, $H$ genetic diversity and chlorotype frequency shown in parentheses

Palmé and Vendramin (2002) in previous studies of hazelnut. Boccacci and Botta (2009) assessed diversity in cultivated forms (75 accessions) from Spain, Italy, Turkey and Iran, and found three sizes at ccmp2, 2 at ccmp3, 2 at ccmp4 and 2 at ccmp10 for a total of four haplotypes. Palmé and Vendramin (2002) found seven haplotypes in wild genotypes from natural forests in 11 European countries. We found the same number of size variants as Palmé and Vendramin (2002) at ccmp2 (3 sizes), ccmp3 (2 sizes) and ccmp10 (2 sizes). At ccmp4, we found the two sizes reported by Boccacci and Botta (2009) rather than just the one reported by Palmé and Vendramin (2002). In our work four polymorphic cpSSR primer pairs resulted in 11 haplotypes, four ( $\mathrm{J}-\mathrm{L}$ ) exclusive to wild genotypes, five $(C-G)$ exclusive to landraces, and two (A and B) shared haplotypes. The detection of exclusive haplotypes found in wild and landrace genotypes is probably due to geographic isolation and absence of plant improvement, respectively, and is clearly shown by the network diagram (Fig. 2). In fact, 13 genotypes from wild genotypes, collected from isolated forest sites in northern Portugal (Fig. 1) produced five different haplotypes, in contrast to the six haplotypes reported by Palmé and Vendramin (2002) who studied 248 wild genotypes from 26 natural populations across Europe. 
This diversity in $C$. avellana in northern Portugal indicates that it was a refuge during the last ice age. Palmé and Vendramin (2002) excluded southern Italy and the Balkans as a source for post-glacial recolonization, as five haplotypes were identified in southeastern Europe but only two in western and northern Europe. The analysis of our samples with other molecular markers (nSSRs, ISSRs, AFLPs) also revealed high diversity. Tzedakis et al. (2002) and Petit et al. (2003) suggested that regions showing high levels of diversity could be identified as a potential refuge. Fossil pollen data (Huntley and Birks 1983) and phylogeographic studies (Hewitt 1996, 2000; Taberlet et al. 1998) show that in Europe the only areas that would have remained viable for the survival of temperate flora were the Iberian (Portugal and Spain), Italian and Balkan peninsula. Species like pine, oak and hazel appear to have been present in all three refuges (Taberlet 1998). Comparison of wild and landrace haplotypes showed clear differences. Haplotype B was not found in wild Portuguese hazelnuts, but is predominant in the landraces. Haplotype $\mathrm{A}$ is present in the landraces, but is rare in the wild genotypes. The existence of the Alvão, Marão, Peneda and Gerês mountains (1,200-1,600 m elevation with a north/ northeast orientation) made gene flow more difficult in the southern direction. The presence of haplotype A in only one wild genotype prompts us to speculate that this accession from the Douro International Natural Park may be the ancestral haplotype for nine landraces. This wild genotype is situated on the rocky cliffs of the Douro river, which would allow easy seed dispersal by birds, small mammals or river flow. Seven of the nine landraces that share haplotype A with this wild genotype are located on the south bank of the Douro River, consistent with a possible ancestral relationship. The presence of natural barriers, like mountains, associated with empirical human selection can help explain differences in distribution between wild and landrace genotypes. It is believed that at the full extent of glacial advance, temperate flora survived in small pockets in environmentally favorable places and there were not broad expanses of trees and shrubs. The more extensive studies of wild and landrace hazels from other European countries would increase our understanding of haplotype distribution, and the origin and evolution of the European hazelnut.

We found a high level of chloroplast haplotype diversity in wild hazelnuts from a relatively small and restricted area. Information on genetic diversity in wild hazels will provide information relevant to diversity conservation as well as breeding. The unique haplotypes identified in wild genotypes suggests that those chlorotypes were excluded when superior plants were chosen from the local vegetation for clonal propagation. Additionally, the low number of wild individuals found in northern Portugal points to a need for shortand long-term conservation of genetic diversity.

Acknowledgments This work was supported by the $\mathrm{PhD}$ grant SFRH/BD/40686/2007 attributed from the Portuguese Foundation of Science and Technology (FCT).

\section{References}

Bandelt HJ, Foster P, Rohl A (1999) Median-joining networks for inferring intraspecific phylogenies. Mol Biol Evol $16: 37-48$

Bassil NV, Botta R, Mehlenbacher SA (2005) Microsatellite markers in the hazelnut: isolation, characterization and cross-species amplification in Corylus. J Am Soc Hortic Sci 130:543-549

Birky CW (1988) Evolution and variation in plant chloroplast and mitochondrial genomes. In: Gottlieb L, Jain S (eds) Plant evolutionary biology. Chapman and Hall, London, pp 23-53

Birky CW (1995) Uniparental inheritance of mitochondrial and chloroplast genes: mechanisms and evolution. Proc Nat Acad Sci USA 92:11331-11338

Boccacci P, Botta R (2009) Investigating the origin of hazelnut (Corylus avellana L.) cultivars using chloroplast microsatellites. Genet Resour Crop Evol 56(6):851-859

Boccacci P, Akkak A, Bassil NV, Mehlenbacher SA, Botta R (2005) Characterization and evaluation of microsatellite loci in European hazelnut (Corylus avellana L.) and their transferability to other Corylus species. Mol Ecol Notes 5:934-937

Boccacci P, Akkak A, Botta R (2006) DNA typing and genetic relationships among European hazelnut (Corylus avellana $\mathrm{L}$.) cultivars using microsatellite markers. Genome 49:598-611

Dumolin S, Démesure B, Petit RJ (1995) Inheritance of chloroplast and mitochondrial genomes in pedunculate oak investigated with an efficient PCR method. Theor Appl Genet 91:1253-1256

Ennos RA, Sinclair WT, Hu XS, Langdon A (1999) Using organelle markers to elucidate the history, ecology and evolution of plant populations. In: Hollingsworth PM, Bateman RM, Gornall RJ (eds) Molecular systematics and plant evolution. Taylor and Francis, London, pp 1-19

FAOstat (2008) Agriculture data. http://faostat.fao.org/site/408/ default.aspx

Galvão HP (1968) A cultura da aveleira. Série de divulgação 36. Direcção-Geral dos Serviços Agrícolas, Serviço de Informação Agrícola, Lisboa

Gokirmak T, Mehlenbacher SA, Bassil NV (2009) Characterization of European hazelnut (Corylus avellana) cultivars using SSR markers. Genet Resour Crop Evol 56:147-172 
Gürcan K, Mehlenbacher SA (2010) Development of microsatellite marker loci for European hazelnut (Corylus avellana L.) from ISSR fragments. Mol Breed 26:551-559. doi:10.1007/s11032-010-9464-7

Gürcan K, Mehlenbacher SA, Botta R, Boccacci P (2010) Development, characterization, segregation, and mapping of microsatellite markers for European hazelnut (Corylus avellana L.) from enriched genomic libraries and usefulness in genetic diversity studies. Tree Genetics Genom 6:513-531. doi:10.1007/s11295-010-0269-y

Hewitt GM (1996) Some genetic consequences of ice ages, and their role in divergence and speciation. Biol J Linn Soc 58:247-276

Hewitt GM (2000) The genetic legacy of the Quaternary ice ages. Nature 405:907-913

Huntley B, Birks HJB (1983) An atlas of past and present pollen maps for Europe: 0-13000 years ago. Cambridge University Press, Cambridge

Ishii T, Xu Y, McCouch SR (2001) Nuclear- and chloroplastmicrosatellite variation in A-genome species of rice. Genome 44:658-666

Kasapligil B (1972) A bibliography on Corylus (Betulaceae) with annotations. Annu Rep North Nut Growers Assoc 63:107-162

Li J, Ge XJ, Cao HL, Ye WH (2007) Chloroplast DNA diversity in Castanopsis hystrix populations in south China. Forest Ecol Manag 243:94-101

Lira CF, Cardoso RS, Ferreira CG, Cardoso MA, Proven J (2003) Longterm population isolation in the endangered tropical tree species Caesalpinia echinata Lam. revealed by chloroplast microsatellites. Mol Ecol 12:3219-3225

McCauley DE (1995) The use of chloroplast DNA polymorphism in studies of gene flow in plants. Trends Ecol Evol 10:198-202

Navascues M, Emerson BC (2005) Chloroplast microsatellites: measure of genetic diversity and the effect of homoplasy. Mol Ecol 14:1333-1341

Pakkad G, Ueno S, Yoshimaru H (2008) Genetic diversity and differentiation of Quercus semiserrata Roxb. in northern Thailand revealed by nuclear and chloroplast microsatellite markers. For Ecol Manag 255:1067-1077

Palmé AE, Vendramin GG (2002) Chloroplast DNA variation, postglacial recolonization and hybridization in hazel, Corylus avellana. Mol Ecol 11:1769-1779

Petit RJ, El Mousadik A, Pons O (1998) Identifying populations for conservation on the basis of genetic markers. Conserv Biol 12:844-855

Petit RJ, Aguinagalde I, de Beaulieu JL, Bittkau C, Brewer S, Cheddadi R, Ennos R, Fineschi S, Grivet D, Lascoux M, Mohanty A, Müller-Starck G, Demesure-Musch B, Palmé A, Martín JP, Rendell S, Vendramin GG (2003) Glacial refugia: hotspots but not melting pots of genetic diversity. Science 300:1563-1565

Powell W, Morgante M, Andre C, McNicol JW, Machray GC, Doy Tingey SV, Rafalski JA (1995) Hypervariable microsatellites provide a general source of polymorphic DNA markers for the chloroplast genome. Curr Biol 5:215-222

Powell W, Morgante M, McDevitt R, Vendramin GC, Rafalski JA (1996) Polymorphic simple sequence repeat regions in chloroplast genomes: applications to the population genetics of pines. Proc Natl Acad Sci USA 92:7759-7763
Provan J, Russell JR, Booth A, Powell W (1999) Polymorphic chloroplast simple sequence repeat primers for systematic and population studies in the genus Hordeum. Mol Ecol 8:505-511

Provan J, Powell W, Hollingsworth PM (2001) Chloroplast microsatellites: new tools for studies in plant ecology and evolution. Trends Ecol Evol 16:142-147

Radetzky R (1990) Analysis of mitochondrial DNA and its inheritance in Populus. Curr Genet 18:429-434

Rajora OP, Dancik BP (1992) Chloroplast DNA inheritance in Populus. Theor Appl Genet 84:280-285

Rajora OP, Mosseler A (2001) Challenges and opportunities for conservation of forest genetic resources. Euphytica 118:197-212

Sebastiani SF, Carnevale S, Vendramin GG (2004) A new set of mono- and dinucleotide chloroplast microsatellites in Fagaceae. Mol Ecol Notes 4:259-261

Silva AP, Santos FA, Santos AS, Sousa VS, Lopes AD, Assunção AV, Mota BS, Leme PC, Carvalho JL, Borges OM, Ribeiro RS, Fernandes ST (2004) Variedades de aveleiras. Agro 162 Project Report, National Publication

Streiff R, Labbe T, Bacilieri R, Steinkellner H, Glössl J, Kremer A (1998) Within-population genetic structure in Quercus robur L. and Quercus petraea (Matt.) Liebl. assessed with isozymes and microsatellites. Mol Ecol 7:317-328

Streiff R, Ducousso A, Lexer C, Steinkellner H, Gloessl J, Kremer A (1999) Pollen dispersal inferred from paternity analysis in a mixed oak stand of Quercus robur L. and $Q$. petraea (Matt.) Liebl. Mol Ecol 8:831-841

Taberlet P (1998) Biodiversity at the intraspecific level: the comparative phylogeographic approach. J Biotechnol 64:91-100

Taberlet P, Fumagalli L, Wust-Saucy AG, Cosson JF (1998) Comparative phylogeography and postglacial colonization routes in Europe. Mol Ecol 7:453-464

Tasias Valls J (1975) El avellano en la provincia de Tarragona. EXCMA Diputación Provincial de Tarragona, Tarragona, Spain

Thompson MM, Lagerstedt HB, Mehlenbacher SA (1996) Hazelnuts, in: Janick J, Moore JN (eds) Fruit breeding: nuts, vol 3. Wiley, New York, pp 125-184

Trotter A (1921) Contributo alla storia colturale del nocciuolo nella Campania. Ristampa di una comunicazione fatta al Congresso di Arboricoltura Meridionale, Napoli, Italy, pp 3-19

Tzedakis PC, Lawson IT, Frogley MR, Hewitt GM (2002) Buffered tree population changes in Quaternary refugium: evolutionary implication. Science 292:267-269

Ueno S, Setsuko S, Kawahara T, Yoshimaru H (2005) Genetic diversity and differentiation of the endangered Japanese endemic tree Magnolia stellata using nuclear and chloroplast microsatellite markers. Conserv Genet 6:563-574

Weising K, Gardner RC (1999) A set of conserved PCR primers for the analysis of simple sequence repeat polymorphisms in chloroplast genomes of dicotyledonous angiosperms. Genome 42:9-19

Yeh FC, Yang RC, Boyle TBJ, Ye ZH, Mao JX (1999) Popgene version 1.32 , the user-friendly shareware for population genetic analysis. Molecular Biology and Biotechnology Centre, University of Alberta, Edmonton 